\title{
Knowledge management model for decision-making through ontologies for an employment and employability observatory
}

Modelo de gestión del conocimiento para la toma de decisiones mediante ontologías para un observatorio de empleo y empleabilidad

Modelo de gestão do conhecimento para a tomada de decisões utilizando ontologias para um observatório do emprego e da empregabilidade

\section{David Alfonso Méndez Beltrán ${ }^{1}$ \\ Duvan Humberto Prieto Suarez ${ }^{2}$ \\ Luz Deicy Alvarado Nieto ${ }^{3}$}

Received: May $18^{\text {th }}, 2021$

Accepted: August $10^{\text {th }}, 2021$

Available: September $6^{\text {th }}, 2021$

How to cite this article:

D. A. Méndez Beltrán, D. H. Prieto Suárez, L. D. Alvarado Nieto, "Knowledge management model for decision-making through ontologies for an employment and employability observatory," Revista Ingeniería Solidaria, vol. 17, no. 3, 2021. doi: https://doi.org/10.16925/2357-6014.2021.03.02

Research article. https://doi.org/10.16925/2357-6014.2021.03.02

1 Facultad de Ingeniería. Universidad Distrital Francisco José de Caldas.

Email: daamendezb@correo.udistrital.edu.co

ORCID: https://orcid.org/0000-0001-5057-0069

CvLAC: https://scienti.minciencias.gov.co/cvlac/visualizador/generarCurriculoCv.do?cod_ $\mathrm{rh}=0001744968$

2 Facultad de Ingeniería. Universidad Distrital Francisco José de Caldas.

Email: dhprietos@correo.udistrital.edu.co

ORCID: https://orcid.org/0000-0002-7883-8394

CvLAC: https://scienti.minciencias.gov.co/cvlac/visualizador/generarCurriculoCv.do?cod_ $\mathrm{rh}=0001744820$

$3 \quad$ Facultad de Ingeniería. Universidad Distrital Francisco José de Caldas.

Email: lalvarado@udistrital.edu.co

ORCID: https://orcid.org/0000-0002-8547-4410

CvLAC: https://scienti.minciencias.gov.co/cvlac/visualizador/generarCurriculoCv.do?cod_ $\mathrm{rh}=0000409308$ 
2 Knowledge management model for decision-making through ontologies for an employment and employability observatory

\section{Abstract}

Introduction: This article is the product of the research "Knowledge management model for decision-making through ontologies for an employment and employability observatory" developed within the ComplexUD Research Group in the Universidad Distrital Francisco José de Caldas between 2018 and 2020.

Objective: The objective of this research is the construction of a knowledge management model using ontologies of the actors involved in the employability process.

Methodology: The construction of knowledge was carried out through the creation of ontologies, which describe the conceptual components of each actor that participates in employability, since their interaction forms the proposed model.

Conclusion: It is observed that representing the actors through ontologies allows modeling the behavior between them in a way that is very close to reality, however, it must be taken into account that the components that describe the actors can change over time, so a periodic update of the model is necessary.

Originality: This document proposes original ideas regarding the definition and behavior of the actors identified in the development of the research; if the work of other authors is mentioned throughout the article, it is cited according to the norms established by its publication.

Keywords: Employability, complexity, knowledge management, ontology, employment observatory.

\section{Resumen}

Introducción: Este artículo es producto de la investigación "Modelo de gestión del conocimiento para la toma de decisiones mediante ontologías para un observatorio de empleo y empleabilidad" desarrollado al interior del Grupo de Investigación ComplexUD de la Universidad Distrital Francisco José de Caldas entre 2018 y 2020. Objetivo: El objetivo de esta investigación es la construcción de un modelo de gestión de conocimiento utilizando ontologías de los actores involucrados en el proceso de la empleabilidad.

Metodología: La construcción de conocimiento se realizó por medio de la creación ontologías, las cuales describen los componentes conceptuales de cada actor que participa en la empleabilidad, dado que la interacción de estos conforma el modelo propuesto.

Conclusión: Se observa que el representar a los actores por medio de ontologías permite modelar el comportamiento entre estos de una forma muy cercana a la realidad, sin embargo, se debe tener en cuenta que los componentes que describen a los actores pueden cambiar con el tiempo, por lo que es necesaria una periódica actualización del modelo.

Originalidad: Este documento propone ideas originales respecto a la definición y comportamiento de los actores identificados en el desarrollo de la investigación, si se menciona el trabajo de otros autores a lo largo del artículo se cita según las normas establecidas por la publicación del mismo.

Palabras clave: Empleabilidad, complejidad, gestión de conocimiento, ontología, observatorio de empleo.

\section{Resumo}

Introdução: Este artigo é o produto da pesquisa "Modelo de gestão do conhecimento para a tomada de decisão através de ontologias para um observatório de emprego e empregabilidade" desenvolvida no Grupo de Pesquisa ComplexUD da Universidade Distrital Francisco José de Caldas entre 2018 e 2020.

Objetivo: o objetivo desta pesquisa é a construção de um modelo de gestão do conhecimento a partir de ontologias dos atores envolvidos no processo de empregabilidade. 
Metodologia: A construção do conhecimento foi realizada por meio da criação de ontologias, que descrevem os componentes conceituais de cada ator que participa da empregabilidade, uma vez que sua interação forma o modelo proposto.

Conclusão: Observa-se que representar os atores por meio de ontologias permite modelar o comportamento entre eles de uma forma muito próxima da realidade, porém, deve-se levar em consideração que os componentes que descrevem os atores podem mudar ao longo do tempo, de forma periódica a atualização do modelo é necessária.

Originalidade: este documento propõe ideias originais quanto à definição e comportamento dos atores identificados no desenvolvimento da pesquisa; se o trabalho de outros autores é citado ao longo do artigo, é citado de acordo com as normas estabelecidas por sua publicação.

Palavras-chave: Empregabilidade, complexidade, gestão do conhecimento, ontologia, observatório do emprego.

\section{INTRODUCTION}

The World Bank, in its report for Latin America, points out that insertion in higher education increased between 2000 and 2013 [1]. It also shows that graduates must acquire skills and knowledge continuously, given that they are expected to constantly change jobs during the next 30 years [2]. Likewise, the trend report of the International Labor Organization (ILO) on the economic growth of Latin America and the Caribbean shows that unemployment is going to decrease slowly due to the different factors found in the labor market of each country [3].

According to Hillage, Pollard, and Britain [4], the process by which a person can quickly find a job is called employability. However, since it appeared as a concept, employability has evolved [5]. For example, the ILO addresses employability as: "transferable skills and qualifications that reinforce people's ability to take advantage of educational and training opportunities that they are presented with a view to finding and keeping a decent job, advancing in the company or changing jobs and adapting to changing technology and labor market conditions" [6].

This has led the Pacific Alliance (PA), and the member countries to seek to improve employability indices, since it is essential for the development of the region and its inhabitants, which is observed in their vision for the year 2030 [7]. In this sense, the EMPLE-AP project has arisen. It proposes the creation of an observatory for labor insertion and strengthening employability in countries of the Pacific Alliance, in order to improve employability indices and insertion of graduates of Higher Education Institutions (HEIs) in the labor market [8].

In the proposed observatory, knowledge management is a vitally important pillar, since it creates an organization based on knowledge, which contributes to accelerating organizational development in direct line with the vision of the Pacific Alliance 
4 Knowledge management model for decision-making through ontologies for an employment and employability observatory

[9]. When proposing a model of this type, the different actors that intervene in the employability process must be taken into account. For this reason, this article proposes a knowledge management model for the EMPLE-AP project, where an approximation is proposed of the behavior of the observatory, through the relationships that exist and the knowledge shared between the actors of the employability process.

\subsection{LITERATURE REVIEW}

The concept of employability has changed over the years and with it, the way of recognizing whether a person is employable or not [10]; the COVID-19 pandemic has made these concepts even more difficult to evidence since many of the activities have moved to the virtual field [11] [12]. Within the development of a country, the ability to acquire a job in the youth acquires great importance, because young people will be the main workforce, however, it must be taken into account that in institutions with virtual education, people in an older than average age range who also seek to participate in employability are graduating, in both cases, the current pandemic conditions have increased unemployment of recent graduates [13]. Whatever the case, the strengthening of soft skills that contribute to the improvement of a person's employability indexes is relevant [14] [46]. Additionally, studies suggest that recent graduates, upon leaving HEls, do not have the technical and professional skills demanded by the labor market, which makes it difficult for developing countries to compete [15]. The relevance of political reforms in the labor market is also observed, which are carried out in order to contribute to the employability and economic improvement of the country [16] [42] . According to the above, employability is defined in a general way as the "country's capacity to articulate actors (State, HEI, Society, Industrial) that allows for the generation of competences and attitudes in the graduate, as well as increasing their probabilities to create or find a job, keep it and move between the roles of the same organization, which satisfies their professional, economic, promotion and development needs throughout their life, which is materialized in the contribution of value that is made to the employer and the society " [17].

The use of knowledge management in organizations according to different authors [18] [19] [40], is applied with the purpose of capturing and integrating tacit and technical knowledge, which make a person employable, preserving and sharing knowledge between the members of an organization; highlighting the importance of the collaboration of the different actors involved for the generation and use of knowledge in the current technological revolution [20]. 
Within knowledge management there are stages as defined in [21], where it begins by defining the cycle of this process [22], then the knowledge management model is defined [23], where it is necessary to define a conceptual framework of work with the one that can be operated. There are several frameworks that stand out because, "they have a holistic approach to knowledge management seeking to be comprehensive and take into account people, processes and organization, and technological dimensions" [24] . These models stand out because they can have an epistemological approach, differentiating between individual knowledge and social knowledge [25]. Others focus on capturing the tacit knowledge of individuals in an organization [26], or because they look at the organization as a complex adaptive system [27], whose agents are those who generate knowledge through understanding, the creation of new ideas, problem solving and decision-making [43] [45].

In knowledge management, modeling tools are used to capture and organize people's information. Specifically, the use of ontologies is proposed since these help to conceptualize, in a formal and explicit way, what one desire s to model, reflecting a shared domain of the concept that seeks to be defined [28]. Although the process of construction of an ontology is more detailed, broadly what is sought is to take the definition of the concept to be modeled, extract the nouns and predicates, which become classes and properties that will make up the ontology [29]; This is done by means of markup languages [30], to characterize the relationships that are generated between classes and the specification of their instances.

In this sense, there are different ways of applying knowledge management within an organization [24] [41] [44], among which is the use of methodologies that define the development stages of the model, described through the construction of ontologies [31] [18] which, as in the case of [32], lead to the construction of web portals, where it is worth highlighting their implementation in the field of an employment and employability observatory.

Consequently, and in order to manage knowledge from and to graduates, the creation of a knowledge management model is proposed, using ontologies to describe the behavior of the actors involved in employability. The purpose of creating these ontologies is to have a clear description of the different entities that interact in an employment observatory, holistically capturing the knowledge of the actors that the observatory will study. It should be noted that the proposed model has limitations in the variables studied; if employability is observed as a complex problem, it would have to be conditioned with more variables in the ontology, as shown in [33].

In order to present, in detail, the characteristics of the proposed proposal, the following topics are developed below. Section 2 describes the methodology used to 
6 Knowledge management model for decision-making through ontologies for an employment and employability observatory

define the ontology and its subsequent construction. Section 3 shows the results of the ontological proposal, which brings together the different descriptions and behaviors of the actors involved; the ontology is then validated by performing a test with the instantiation of the different actors. Section 4 discusses the proposal and the test results of the previous section, and finally, Section 5 presents the conclusions.

\section{METHODOLOGY}

This article describes the construction of the knowledge management model based on the proposal of [18]; however, Activity 4 was omitted, given the difference in context with respect to what is proposed here, being necessary to renumber the activities.

This two-step methodology begins with the "Organization of knowledge", which is made up of several activities, the first is to identify requirements given the expertise of the knowledge engineer, as shown in F igure 1; for this case, such requirements were related to the components of the definition of employability. Subsequently, the key concepts and the corresponding rules are identified within an incremental process together with the first activity; in this case, concepts such as labor market, IES, state and graduates were defined. For the model presented here, the characteristics of each of the actors, as well as their interaction and with the observatory, were determined. In this way, the ontological base or CRO (Core Reference Ontology) is generated, taking the keywords and classifying them to produce a specific taxonomy . In this sense, each concept was characterized as follows: the state, through which policies regulate the other actors; the HEls, observing the organizational distribution of the faculties, institutes, research units, and departments attached to them; the labor market, taking into account employment agencies, and studies on entering the productive sector [3] [17]; graduates, made up of intrinsic data (hard and soft skills) and extrinsic data (courses, studies and experience); and finally, employment observatories that are already operating in different countries [31] [32]. Then, for each of the actors, a version is generated and validated, finally integrating the one that best fits its description, giving rise to the domain specific ontology or DSO (Domain Specific Ontology). 


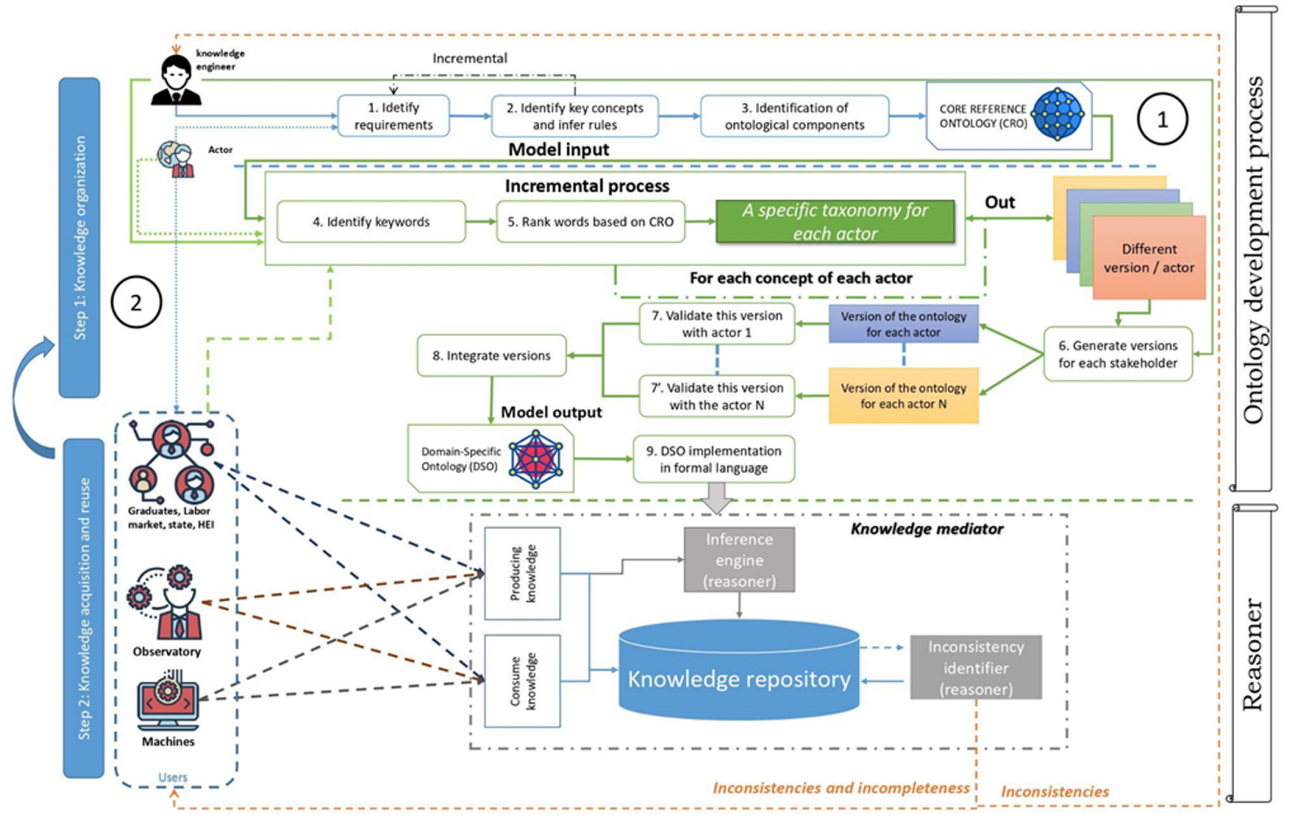

Figure 1. Two-step methodology in the formalization of knowledge based on [18].

Step two, with which the construction of the ontology is completed, is called "acquisition and reuse of knowledge", starting with the implementation of the DSO, which is deployed through the tool used (knowledge mediator), which is composed of: the inference engine (ontological reasoner), the repository, and the inconsistency identifier. At this point, it is worth mentioning that the knowledge mediator used is Protegé [34]. For the production and construction of knowledge, the users of the mediator are established, which are people outside the observatory who may belong to groups of graduates, be part of the labor market, state institutions or HEls. Finally, the machines that will serve to enter and consult data, with the purpose of acquiring and sharing knowledge, are taken into account.

At the end of this second step, the inconsistencies and incomplete aspects identified by the mediator are addressed, where the representation of the users must be integrated into the adjusted knowledge, to provide new details and corrections to the ontology, which will have a direct impact on the model [35].

It should be clarified that, for the purpose of this article, the participation of the actors mentioned in the first step of the methodology is not counted on, because the knowledge engineer is the one who has an overview of the observatory, based on the theoretical definitions found. In the literature, in the same way, this first version only covers the validation of the model [36]. 
8 Knowledge management model for decision-making through ontologies for an employment and employability observatory

\section{RESULTS}

\subsection{Knowledge management model}

The proposed ontology (CRO) is made up of five entities as shown in Figure 2:

- Graduate: It is a person trained and titled in an educational institution.

- HEl: Autonomous higher education institutions that train future graduates in the different disciplines.

- Labor Market: Behavior of employment in the country according to the needs of employers, businesses, independent workers, etc., in relation to graduates.

- Observatory: It is responsible for studying the behavior of the labor market, HEls, graduates and national policies, in order to make recommendations to the different actors, in order to improve employability.

- State: It is in charge of issuing policies that regulate the labor market, HEls and the graduate.

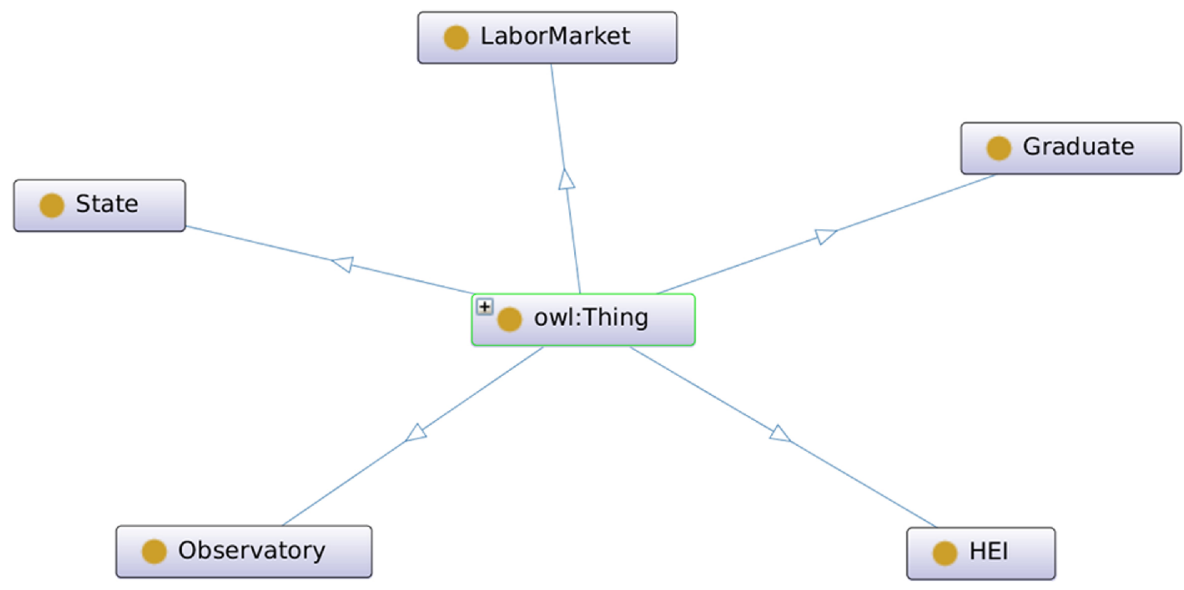

Figure 2. Ontological Model.

Source: own work.

\subsubsection{Graduate Model}

The graduate (as shown in Figure 3) represents a person trained in a specific area (engineering, science, pedagogy, humanities, arts, etc.), possessing skills that allows them to practice in that area. Throughout their training at HEls they acquire skills (hard or soft), which they will use in professional practice; furthermore, they have a 
series of attitudes that predispose him to carry out his activities. Likewise, they can count on some work experience that will affect the aforementioned variables.

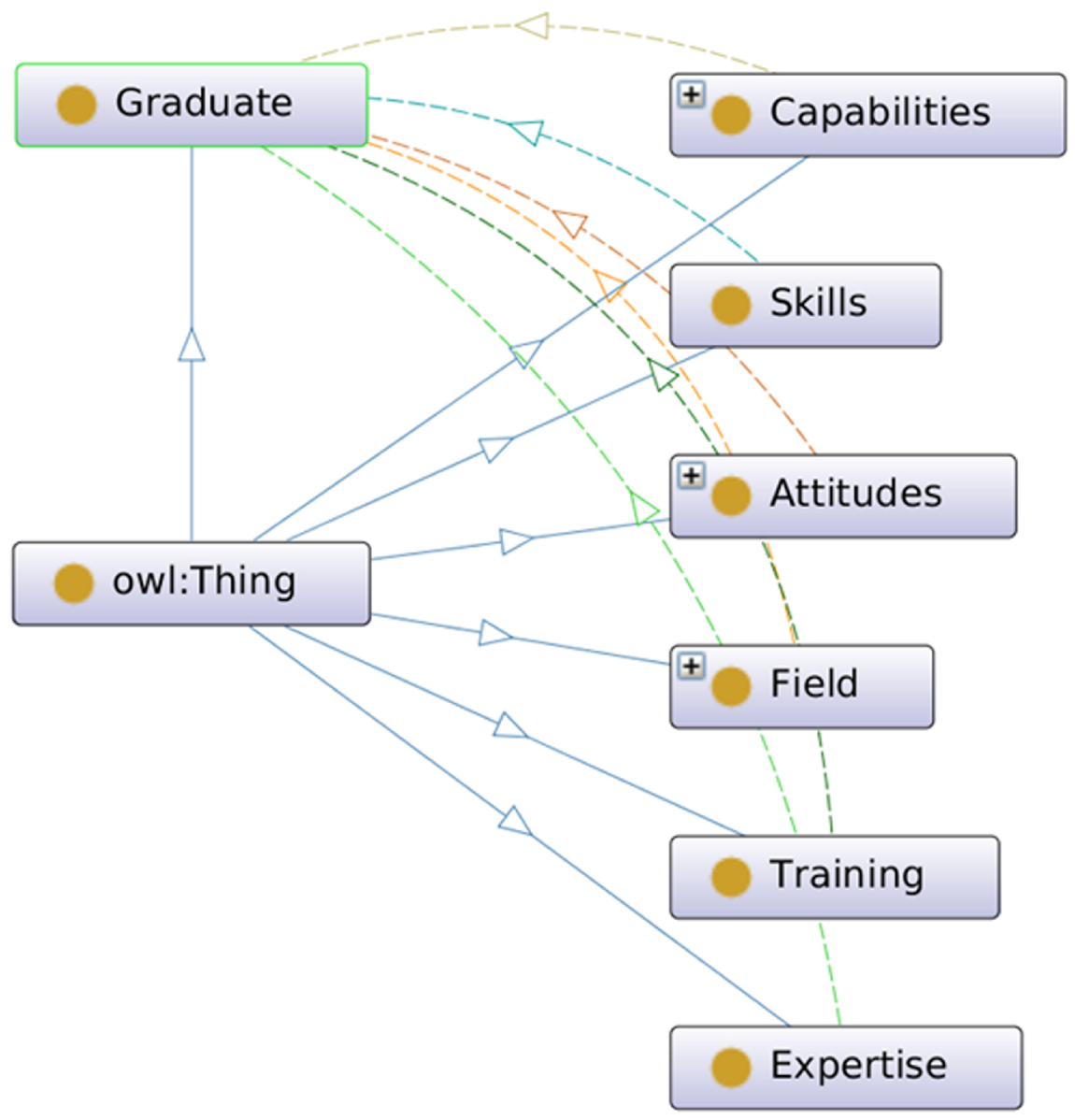

Figure 3. Graduate Model. Source: own work.

\subsubsection{Higher Education Institutions Model}

The HEls, in order to train future graduates, offer study programs which are classified into areas of knowledge (engineering, sciences, humanities, pedagogy, arts, etc.). In turn each area can be divided into training cycles (foundation, deepening and optional). Finally, they can have institutes, whether for research, extension, etc., as evidenced in Figure 4. 


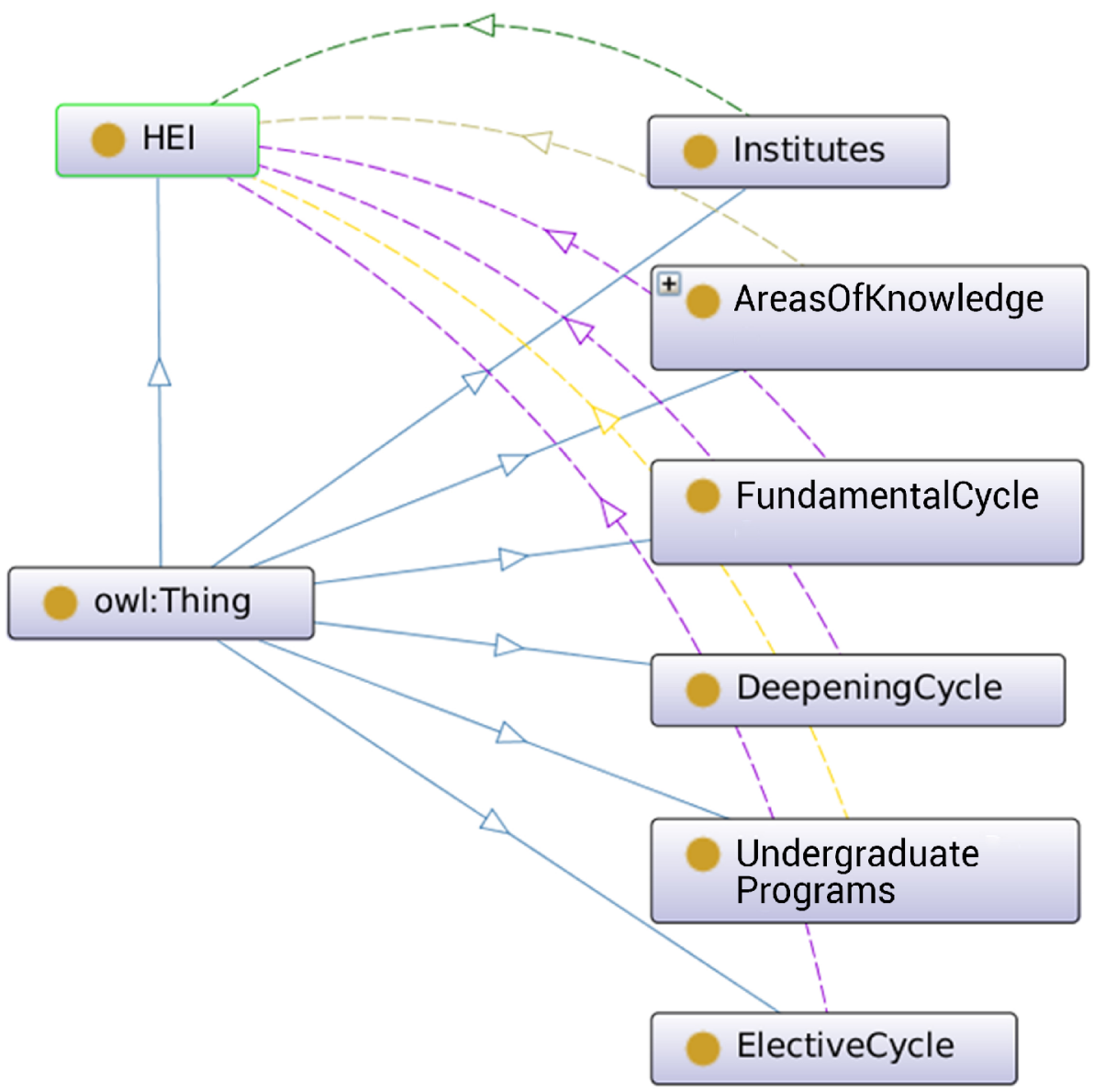

Figure 4. Higher Education Institution Model.

Source: own work.

\subsubsection{Labor Market Model}

The labor market (Figure 5) is where graduates interact with companies, which may belong to one of two different productive sectors (public or private) . In this market, a supply and a demand are handled, which the HEls will have in consideration when proposing adjustments in their academic programs . In addition, it takes into account how globalization and emerging knowledge affect the market through research, development and innovation. 


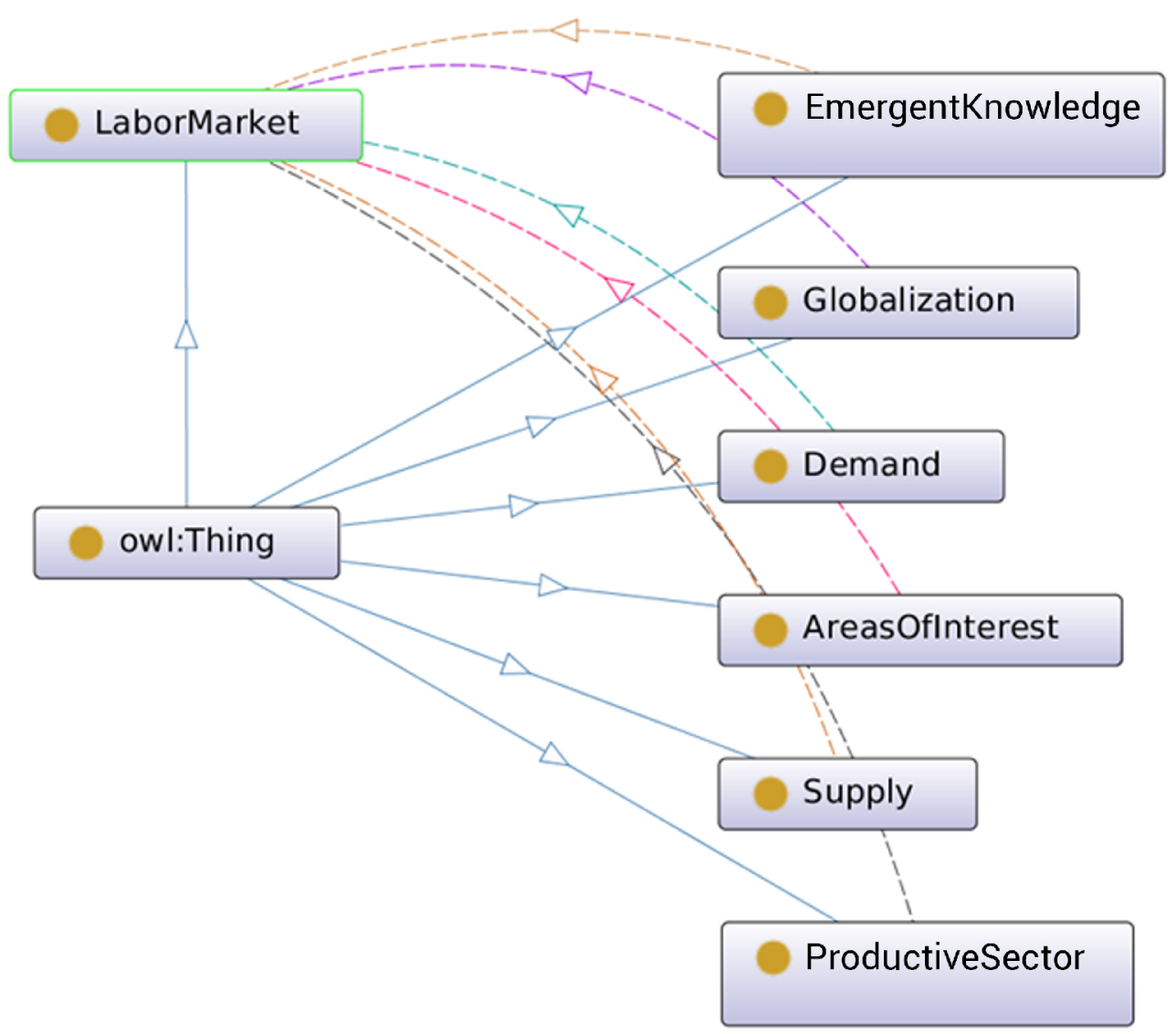

Figure 5. Labor Market Model.

Source: own work.

\subsubsection{Observatory Model}

The observatory is an independent entity that brings together the other actors and is in charge, among other things, of analyzing their interaction with them. Likewise, it generates guidelines, suggestions and studies to guide the decision-making of the rest of the actors, as presented in Figure 6. 

employability observatory

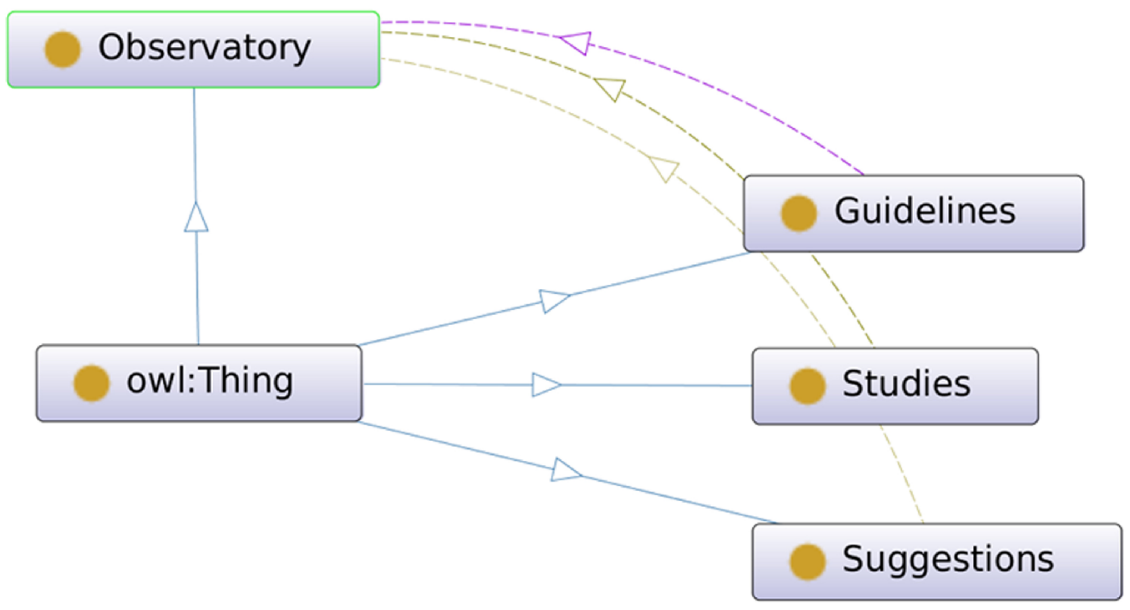

Figure 6. Model of the Observatory.

Source: own work.

\subsubsection{State Model}

The state controls, through its national policies, the other entities proposed in the ontology (see Figure 7), generating guidelines and programs to regulate and encourage education, as well as guidelines on labor and economic matters that directly affect the labor market, HEls and graduates.

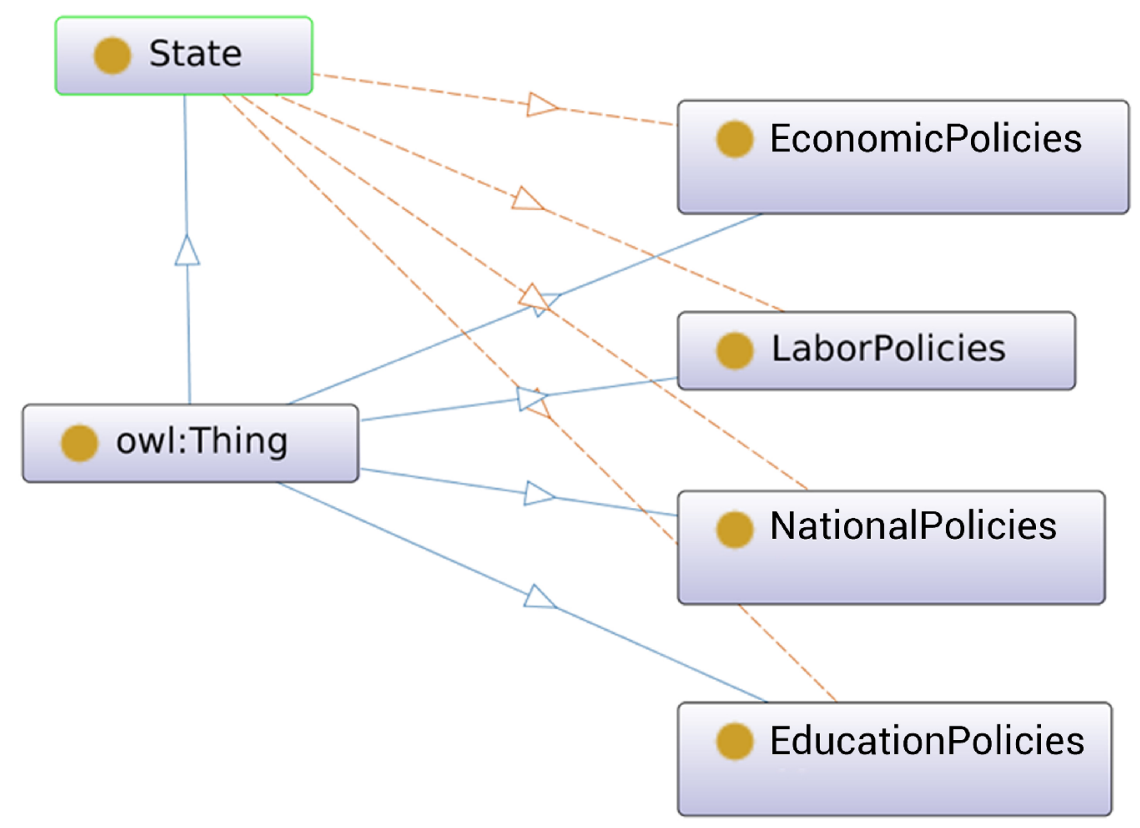

Figure 7. State Model.

Source: own work. 


\subsection{Validation}

By defining the object and data constraints, different preliminary results can be obtained in the functionality of the ontology.

To begin with, it is possible to see that by making use of the knowledge mediator (reasoner), the extended classes of each ontology are reorganized in the inference view, explicitly showing that they are subclasses of their corresponding parent hierarchies (actors in the proposed model), see $\mathrm{F}$ igure 8.

It is also possible to create instances of state policies, graduates, companies and HEls, from a set of data (dataset) . In this way, through the observatory, it is sought to carry out studies, find possible suggestions to the involved actors and establish the guidelines with which it will act.

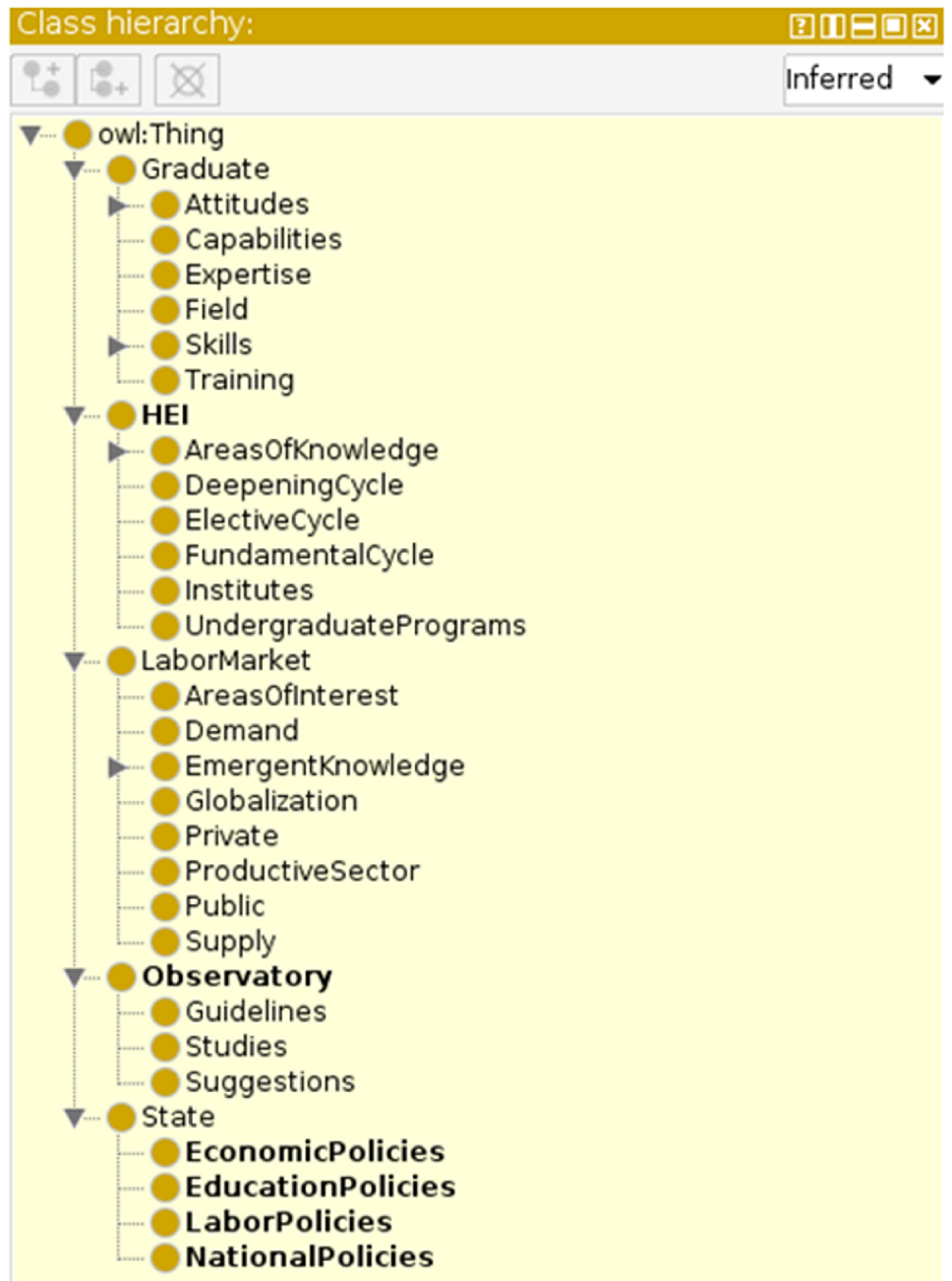

Figure 8. Hierarchy inferred with the reasoner. Source: own work. 
Knowledge management model for decision-making through ontologies for an employment and employability observatory

Finally, it is possible, through the query component (DL QUERY), to ask simple questions that verify the behavior of the instances created, in order to validate the correct definition of the ontology. Two examples will be shown below, the first corresponds to the instance of a graduate profile ( Figure 9), and the other to a company in the labor market ( Figure 10).

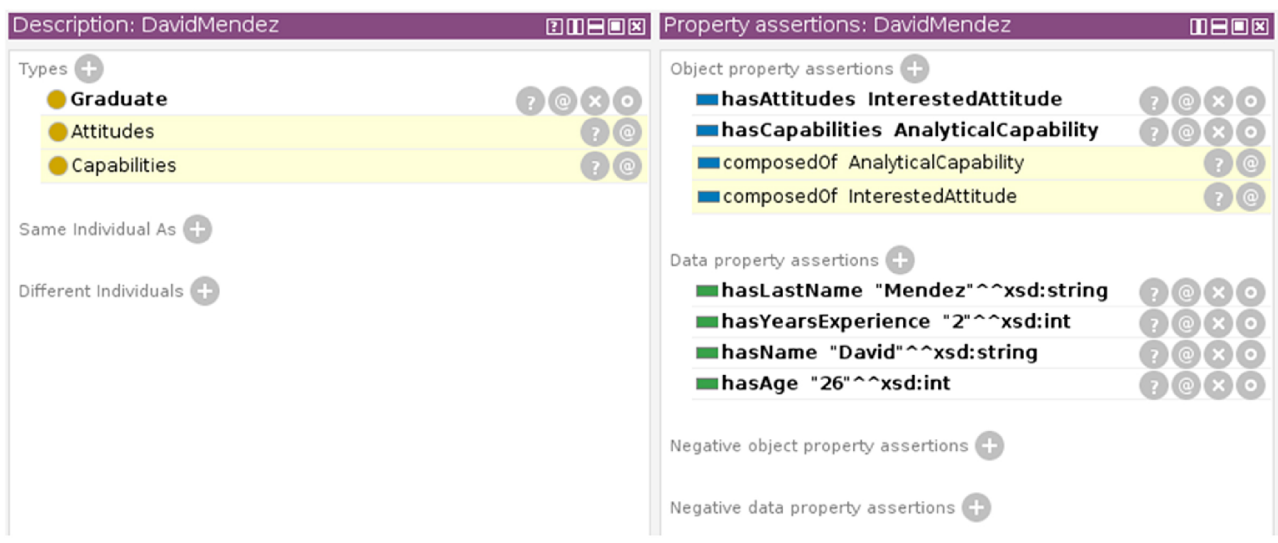

Figure 9. Description of the "DavidMendez" instance.

Source: own work.

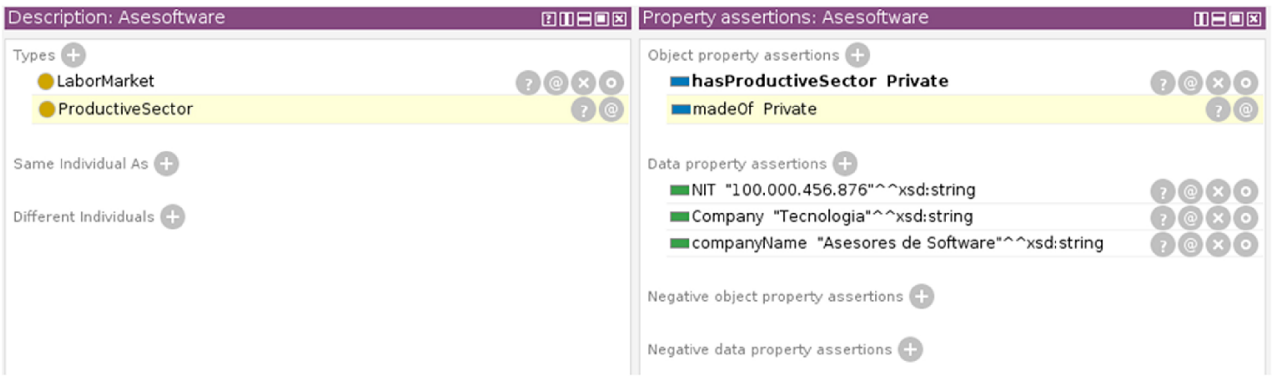

Figure 10. Description of the "Asesoftware" instance.

Source: own work.

As indicated, to validate the instances, the reasoner is used with the examples proposed in Figures 11 and 12, in which, through the defined sentence, it is inferred that if a company seeks a profile with analytical capacity, it would obtain the instances of graduates with such an aptitude ; in this case "DavidMendez". It is also possible that if a graduate is applying to a company that is looking for their particular skills and knowledge, the reasoner infers the instances of organizations in the private productive sector, in the case of the example: "Asesoftware". 


\begin{tabular}{|c|c|}
\hline DL query: & 브미 \\
\hline \multicolumn{2}{|l|}{ Query (class expression) } \\
\hline \multicolumn{2}{|c|}{ hasCapabilities value AnalyticalCapability } \\
\hline Execute Add to ontology & \\
\hline \multicolumn{2}{|l|}{ Query results } \\
\hline \multirow[t]{2}{*}{ Equivalent classes $(0$ of 0$)$} & Query for \\
\hline & $\checkmark$ Direct superclasses \\
\hline Superclasses ( 3 of 3 ) & $\checkmark$ Superclasses \\
\hline Capabilities & $\checkmark$ Equivalent classes \\
\hline Graduate & Direct subclasses \\
\hline \multirow[t]{2}{*}{ owl:Thing } & $\checkmark$ Direct subclasses \\
\hline & $\checkmark$ Subclasses \\
\hline Direct superclasses ( 1 of 1 ) & $\checkmark$ Instances \\
\hline \multicolumn{2}{|l|}{ Capabilities } \\
\hline Direct subclasses (1 of 1 ) & Result filters \\
\hline owl:Nothing & Name contains \\
\hline \multicolumn{2}{|l|}{ Subclasses ( 1 of 1 ) } \\
\hline owl:Nothing & $\begin{array}{l}\text { Display owl:Thing } \\
\text { (in superclass results) }\end{array}$ \\
\hline Instances ( 1 of 1 ) & $\begin{array}{l}\checkmark \text { Display owl:Nothing } \\
\text { (in subclass results) }\end{array}$ \\
\hline
\end{tabular}

Figure 11. Execution of the reasoner looking for profiles of graduates with analytical capacity.

Source: own work.

\begin{tabular}{|c|c|}
\hline DL query: & m曰口园 \\
\hline \multicolumn{2}{|l|}{ Query (class expression) } \\
\hline \multicolumn{2}{|c|}{ hasProductiveSector value Private } \\
\hline Execute Add to ontology & \\
\hline \multicolumn{2}{|l|}{ Query results } \\
\hline \multirow[t]{2}{*}{ Equivalent classes ( 0 of 0 ) } & Query for \\
\hline & $\checkmark$ Direct superclasses \\
\hline Superclasses ( 3 of 3 ) & $\checkmark$ Superclasses \\
\hline LaborMarket & $\checkmark$ Equivalent classes \\
\hline Productivesector & $\checkmark$ Direct subclasses \\
\hline \multirow[t]{2}{*}{ owl:Thing } & Direct subclasses \\
\hline & $\checkmark$ Subclasses \\
\hline Direct superclasses (1 of 1 ) & $\checkmark$ Instances \\
\hline \multicolumn{2}{|l|}{ Productivesector } \\
\hline Direct subclasses ( 1 of 1 ) & Result filters \\
\hline owl:Nothing & Name contains \\
\hline \multicolumn{2}{|l|}{ Subclasses ( 1 of 1 ) } \\
\hline owl:Nothing & $\begin{array}{l}\checkmark \text { Display owl:Thing } \\
\text { (in superclass results) }\end{array}$ \\
\hline Instances ( 1 of 1 ) & $\begin{array}{l}\text { Display owl:Nothing } \\
\text { (in subclass results) }\end{array}$ \\
\hline
\end{tabular}

Figure 12. Execution of the reasoner looking for companies in the labor market.

Source: own work. 
Knowledge management model for decision-making through ontologies for an employment and employability observatory

Finally, the validation between two characteristics of different actors is carried out; on the one hand, the area of interest of the company and, on the other, the aptitude of a graduate, which would be taken as a connection point between the actors as shown in Figure 13.

\begin{tabular}{|c|c|c|}
\hline DL query: & & 回日回圂 \\
\hline \multicolumn{3}{|l|}{ Query (class expression) } \\
\hline \multicolumn{3}{|c|}{ hasCapabilities value AnalyticalCapability or areaOfInterest value "BI" } \\
\hline Execute Add to ontology & & \\
\hline \multicolumn{3}{|l|}{ Query results } \\
\hline Equivalent classes $(0$ of 0 ) & & Query for \\
\hline & & $\checkmark$ Direct superclasses \\
\hline Superclasses (1 of 1 ) & & $\checkmark$ Superclasses \\
\hline owl:Thing & (3) & $\checkmark$ Equivalent classes \\
\hline Direct superclasses (1 of 1 ) & & $\checkmark$ Direct subclasses \\
\hline owl:Thing & ? & $\checkmark$ Subclasses \\
\hline & & $\checkmark$ Instances \\
\hline Direct subclasses (1 of 1$)$ & & \\
\hline owl:Nothing & ? & Result filters \\
\hline Subclasses ( 1 of 1$)$ & & Name contains \\
\hline owl:Nothing & ? & \\
\hline Instances (2 of 2) & & $\checkmark$ Display owl:Thing \\
\hline Asesoftware & ? & (in superclass results) \\
\hline DavidMendez & (3) & $\begin{array}{l}\text { Display owl:Nothing } \\
\text { (in subclass results) }\end{array}$ \\
\hline
\end{tabular}

Figure 13. Execution of the reasoner looking for an area of interest of a company with the aptitude of analytical capacity.

Source: own work.

\section{DISCUSSION}

Two aspects are addressed below, which can generate controversy in the process of building the ontology.

\subsection{The actors involved in employability}

To pigeonhole the word employability as a simple concept, where a person has the possibility of getting a job [9], is a reductionist vision and represents a bias to everything that happens at the moment in which they are employed. There are authors who delve into this topic [14] [15] [16] providing a more global opinion of the concept, where it can be interpreted that there are key elements to define employability. In this way, this article proposes the modeling of the actors involved in employability, based 
on these elements, and with contributions from more elaborate definitions, presented in [6] [17].

The proposed model of knowledge management seeks to connect the concepts of the actors, in order to understand the repercussions that are mutually generated. These concepts, as shown in Figure 1, are defined by a taxonomy which can be seen in Figures 3, 4, 5, 6 and 7; where the characteristics of each actor are evidenced, thus giving rise to the corresponding taxonomy. In the case of graduates, the areas in which they were trained, the possible skills they would have and the experience obtained were taken into account; the state was defined, taking into account its importance in the generation of policies that can affect other actors. In the HEl, the composition of the areas of knowledge and how they are organized depending on the institution was studied; for the labor market, the productive sectors, their supply and demand, as well as emerging knowledge within globalization were taken into account. Finally the observatory was considered, where the other actors interact generating knowledge through suggestions, guidelines and studies.

\subsection{A knowledge management model using ontologies}

In practice, organizations use knowledge management models [18] [19]; in this way proposing one based on ontologies is not new [18] [29] [30]. In this sense, the model presented seeks to give an input to the observatory ; not only so that it works in the development of its information system [31], but so that it serves in the construction of its processes and procedures, its vision, its mission, its stakeholders and other benefits that it can bring to the same.

Once the ontology was built according to the definition of the actors and their relationships, the validation (S ection 3.2) was based on the use of the reasoner including a minimum sample of data (instances); thus, through the inference of the implemented rules and queries, it obtains specific information about an actor. In the validation, data were entered for instances of two different hierarchies, one as a graduate and the other as part of the labor market, where the characteristics that define them are reflected (Figures 9 and 10), and according to the reasoning, the inference between them is made by means of DL QUERY (Figures 11 and 12). To finish, a consultation was developed, which shows through the characterization of its concepts, the connection between two actors ( Figure 13). In this sense, the model allows us to observe how the actors can be related in the general ontology, thus validating its consistency. It should be clarified that said validation was carried out for the sample presented; however, it would work the same if one wanted to evaluate with a large amount of data. 
Indeed, the general ontology highlights the way in which the actors involved in employability are related, it should be noted that the model has not been validated in real situations because it is necessary to have data on people, companies and to take into account the impact of legislation of the government on education and the labor market, which directly affect the graduate. A simple example of this is the measures taken in the collective confinement, within the health crisis caused by COVID-19, where the unemployment rate increased, the measures to the labor market had an impact on the purchasing power of employees, and the quality of education was affected; this will possibly affect future graduates.

\section{CONCLUSIONS}

When considering the proposed knowledge management model, through different actors, it is possible to achieve studies from a holistic perspective, where the employability observatory should constantly monitor the elements of the model raised in this research.

In the proposed model, the observatory fulfills the role of studying how the actors behave (S ection 3.1); however, it must be taken into account that they change over time, very possibly leading to an update of the model. In this way, instances or objects closer to real life can be created.

The constant change in the behavior of the actors belonging to the proposed model, makes the general behavior of the model similar to that of Complex Adaptive Systems (CAS) . In this way, it is proposed as future work, validating with real data, as it is a complex system with interconnected and adaptive actors, continuously improving according to globalization and the challenges that arise in society, [37],[38], [39].

\section{REFERENCES}

[1] M. Ferreyra, C. Avitabile, J. Botero, F. Haimovich, S. Urzúa and Banco Mundial, "At a Crossroads: Higher Education in Latin America and the Caribbean”, pp. 1, 2017. [Online]. Available: https:// openknowledge.worldbank.org/handle/10986/26489

[2] O. (OTI), "El futuro del trabajo que queremos La voz de los jóvenes y diferentes miradas desde América Latina y el Caribe," Perfiles Educativos, vol. 40, no. 159, pp. 194-210, 2018 , doi: https:// doi.org/10.22201/iisue.24486167e.2018.159.58775. 
[3] Organización Internacional del Trabajo, "World Employment and Social Outlook," vol. 2019, no. 1, pp. 1, 2019, doi: https://doi.org/10.1002/wow3.2019.2019.issue-1

[4] J. Hillage, E. Pollard and G. Britain, "Employability: Developing a framework for policy analysis”, London: Department for Education and Employment, pp. 1, 1998.

[5] M. Fugate and A. Kinicki, "A dispositional approach to employability: Development of a measure and test of implications for employee reactions to organizational change," Occupational and Organizational Psychology, vol. 81, no. 3, pp. 503-527, 2008, doi: https:// doi.org/10.1348/096317907×241579

[6] C. Mallado, S. Parejo and R. Guil, "Competencias implicadas en la empleabilidad: una propuesta desde la igualdad de género," Faces De Eva: Estudos Sobre A Mulher, vol. 35, pp. 1, 2016. [Online]. Available: https://www.researchgate.net/publication/312523756_Competencias_ implicadas_en_la_empleabilidad_una_propuesta_desde_la_igualdad_de_genero.

[7] Alianza del Pacífico, "Alianza Del Pacífico Visión 2030", pp. 1, 2018. [Online]. Available: https:// alianzapacifico.net/wp-content/uploads/V.-final-ALIANZA-DEL-PACIFICO-V2030-version-final-julio-24.pdf

[8] Emple-AP, “Emple-AP”, pp. 1, 2017. [Online]. Available: https://www.emple-ap.com/es/ emple-ap.

[9] M. Aghmiyoni and H. Salimi, "A new applicable knowledge management model to develop innovativeness in a small and medium-sized enterprise research and development center," 2015 IEEE International Conference on Industrial Engineering and Engineering Management (IEEM), pp. 1, 2015, doi: https://doi.org/10.1109/IEEM.2015.7885192.

[10] S. Williams, L. J. Dodd, C. Steele, R. Randall, "A systematic review of current understandings of employability," Journal of Education and Work, pp. 1, 2015, doi: https://doi.org/10.1080/13 639080.2015.1102210.

[11] L. Morales, M.L. Bonilla and J. Pulido, "Effects of the Covid-19 Pandemic on the Colombian Labor Market: Disentangling the Effect of Sector-Specific Mobility Restrictions ," Borradores De Economía, 1129. pp. 1, 2020, doi: https://doi.org/10.32468/be.1129

[12] J. Weller, La pandemia del COVID-19 y su efecto en las tendencias de los mercados laborales. Cepal.org. 2021, pp. 1, doi: https://www.cepal.org/es/publicaciones/45759-la -pandemia-covid-19-su-efecto-tendencias-mercados-laborales. 
Knowledge management model for decision-making through ontologies for an employment and employability observatory

[13] R. Maurizio, Ilo.org. 2021, pp. 1, 2021 . [Online]. Available: https://www.ilo.org/wcmsp5/ groups/public/---americas/---ro-lima/documents/publication/wcms_779114.pdf.

[14] M. M. Pheko, K. Molefhe, "Addressing employability challenges: a framework for improving the employability of graduates in Botswana," International Journal of Adolescence and Youth, 2016. pp. 1, doi: https://doi.org/10.1080/02673843.2016.1234401.

[15] C. J. Lombana, S. A. Muñoz, "Competitividad, educación y empleabilidad: consideraciones para el desarrollo de los países," Clío América, vol. 11, no. 22 , pp. 169-176, doi: https://doi. org/10.21676/23897848.2437

[16] N. Vettas, G. Gatopoulos, A. Louka, I. Polycarpou, "Evaluating the Impact of Labour Market Reforms in Greece during 2010-2018," Hellenic Observatory Research Calls Programme, pp. 1, 2019. [Online]. Available: https://www.Ise.ac.uk/Hellenic-Observatory/Assets/Documents/ Research/New-Research-Programme/2019/Evaluating-the-Impact-of-Labour-MarketReforms-in-Greece-during-2010-2018-Briefing-Report.pdf

[17] L. E. Bohórquez Arévalo, A. X. Sierra Contreras, "Approach To The Concept Of Employability And Its Indicators An Emple-Ap Case Project," Revista Ingeniería Solidaria, vol. 16, no. 3, pp. 1, 2020 , doi: https://doi.org/10.16925/2357-6014.2020.03.10.

[18] E. Mezghani, E. Exposito, K. Drira, A collaborative methodology for tacit knowledge management: Application to scientific research, Future Generation Computer Systems, pp. 1, 2015 , doi: http://dx.doi.org/10.1016/j.future.2015.05.007.

[19] J. Prarthana and S. Sanjeev, "Research Paper On Issues And Challenges In Knowledge Management With Respect To Employability," Accent Journal Of Economics Ecology \& Engineering, vol. 3, no. 9, pp. 1, 2018. . [Online]. Available: http://www.ajeee.co.in/index.php/ AJEEE/article/view/1212/1268.

[20] J. I. Palacios Osma, F. L. Moreno Salazar, K. N. Morales Gómez, "Knowledge Management and Industry 4.0 and Open Innovation," Revista Ingeniería Solidaria, vol. 16, no. 2, pp. 1, 2020 , doi: https://doi.org/10.16925/2357-6014.2020.02.09

[21] K. Dalkir, "Introduction to knowledge management in theory and practice" in Knowledge management in theory and practice, 1st ed. United States: Elsevier, pp. 1-24, 2005.

[22] K. Dalkir, "The knowledge management cycle" in Knowledge management in theory and practice, 1st ed. United States: Elsevier, pp. 25-46, 2005. 
[23] K. Dalkir, "Knowledge management models" in Knowledge management in theory and practice, 1st ed. United States: Elsevier, pp. 47-74, 2005.

[24] K. Dalkir, Knowledge management in theory and practice, 1st ed. United States: Elsevier, pp. 49, 2005.

[25] J. Roos and G. Von Krogh, "Organizational Knowledge, Individualized (and Socialized)," Organizational Epistemology. London: Palgrave Macmillan Limited, pp. 49-68, 1995 , doi: https://doi.org/10.1007/978-1-349-24034-0_4

[26] I. Nonaka and H. Takeuchi, "The Knowledge-creating company: How Japanese companies create the dynamics of innovation," Research Policy, vol. 26, no. 4-5, pp. 598-600, 1997, doi: https://doi.org/10.1016/s0048-7333(97)80234-x.

[27] A. Bennet and D. Bennet, Organizational Survival in the New World: The Intelligent Complex Adaptive System. Amsterdam: Elsevier, pp. 1, 2004.

[28] M. Ivanović and Z. Budimac, "An overview of ontologies and data resources in medical domains," Expert Systems with Applications, vol. 41, no. 11, pp. 5158-5166, 2014, doi: https://doi. org/10.1016/j.eswa.2014.02.045.

[29] S. Miranda, F. Orciuoli, V. Loia and D. Sampson, "An ontology-based model for competence management," Data \& Knowledge Engineering, vol. 107, pp. 51-66, 2017, doi: https://doi.org/10.1016/j.datak.2016.12.001.

[30] A. Gomez-Perez and O. Corcho, "Ontology languages for the Semantic Web," IEEE Intelligent Systems, vol. 17, no. 1, pp. 54-60, 2002, doi: https://doi.org/10.1109/5254.988453.

[31] Z. Gulnaz and B. Tatiana, "The implementation of a knowledge management system model," 2014 IEEE 8th International Conference on Application of Information and Communication Technologies (AICT), Astana, 2014, pp. 1-5, 2014, doi: https://doi.org/10.1109/ ICAICT.2014.7035945.

[32] A. García, J. Cruz and J. García, "Analysis of knowledge management experiences in spanish public administration ," Proceedings of the 3rd International Conference on Technological Ecosystems for Enhancing Multiculturality - TEEM, pp. 1, 2015, doi: https://doi. org/10.1145/2808580.2808609

[33] L. F. Hernández Corredor, R. S. Beltrán Martínez "Employability as a Complex Problem," Revista Ingeniería Solidaria, vol. 16, no. 2, pp. 1, 2020, doi: https://doi.org/10. $16925 / 2357-6014.2020 .02 .01$ 
Knowledge management model for decision-making through ontologies for an employment and employability observatory

[34] M. Musen, "The protégé project," Al Matters, vol. 1, no. 4, pp. 4-12, 2015, doi: https://doi. org/10.1145/2757001.2757003.

[35] S. Álvarez Lebrum, O. M. Salazar, y D. A. Ovalle, "Hacia un modelo ontológico de aprendizaje colaborativo basado en agentes," Revista vínculos, vol. 13, no. 1, pp. 45-55, jun. 2016, doi: https://doi.org/10.14483/2322939X.11581

[36] R. E. Valero Vargas, J. J. Palacios Rozo, y R. González Silva, “Tecnologías de la Información y la Comunicación y los Objetos Virtuales de Aprendizaje: un apoyo a la presencialidad," Revista vínculos, vol. 16, no. 1, pp. 82-91, jun. 2019, doi: https://doi.org/10.14483/2322939X.15537

[37] A. C. Lemus Pinto, C. A. Garzón Sogamoso, y G. M. Tarazona Bermúdez, "Tic en gestión de la cadena de suministro bogotana," Visión Electrónica, vol. 10, no. 2, pp. 195-202, 2016, doi: https://doi.org/10.14483/22484728.11653

[38] C. H. Caicedo y A. Smida, "Intensidad informacional para la longitudinalidad asistencial en sistemas de salud," Visión electrónica, vol. 10, no. 1, pp. 83-95, jun. 2016, doi: https://doi. org/10.14483/22484728.11612

[39] J. F. Herrera-Cubides, P. A. Gaona-García, C. E. Montenegro-Marín, S. Sánchez-Alonso, y D. Martin-Moncunill, "Abstraction of linked data's world," Visión electrónica, vol. 13, no. 1, pp. 57-74, feb. 2019, doi: https://doi.org/10.14483/22484728.14397

[40] J. Soto Lozada. "Factor de competitividad financiera y contable de las organizaciones en Cartagena," Enfoque Disciplinario, vol. 1, no. 1, pp. 1-13. 2016. [Online]. Available: http://enfoquedisciplinario.org/revista/index.php/enfoque/article/view/4

[41] N. M. Salas de Gómez, "Desarrollo social de la nueva PDVSA: una mirada desde la perspectiva cualitativa - Primera Parte," Enfoque Disciplinario, vol. 3, no. 1, pp. 18-47. 2018. [Online]. Available: http://enfoquedisciplinario.org/revista/index.php/enfoque/article/view/11

[42] L. Durán Velásquez, "Estrategia de gestión basada en el cuadro de mando integral para la empresa Herrametal C.A. ubicada en municipio Iribarren, Estado Lara," Enfoque Disciplinario, vol, 3, no. 1, pp. 49-71. 2018. [Online]. Available: http://enfoquedisciplinario.org/revista/index.php/enfoque/article/view/12

[43] F. Agredo Satizábal. "Impacto de las TIC en la competitividad empresarial soportada por un modelo de educación digital," Enfoque Disciplinario, vol. 4, no. 1, pp. 37-50. 2019. [Online]. Available: http://enfoquedisciplinario.org/revista/index.php/enfoque/article/view/20 
[44] L. Niebles Núñez, S.J. De La Ossa Guerra y K.D. González Martínez. "Gestión humana en pymes: herramientas para organizaciones altamente efectivas," Aglala, vol. 10, no. 2, pp. 111 121. 2019. [Online]. Available: http://revistas.curnvirtual.edu.co/index.php/aglala/article/ view/1437

[45] E. De la Hoz Granadillo, J. Morelos Gómez y L. López Polo , "Evaluación de la competitividad comercial del sector industrial colombiano mediante el coeficiente de apertura exportadora," Aglala, vol. 10, no. 1, pp. 180-195. 2018. [Online]. Available: http://revistas.curnvirtual.edu. co/index.php/aglala/article/view/1343

[46] E. Carballo Mass, E. "Modelo de negocio para una tienda virtual de venta de llantas al sector público mediante la modalidad de contratación," Conocimiento Global, vol. 2 no. 1, pp. 20-40. 2017. [Online]. Available: http://conocimientoglobal.org/revista/index.php/cglobal/article/ view/14 